\title{
GESKIEDENIS, GELOOF EN DIE EVANGELIES. PERSPEKTIEWE OP DIE VERHOUDING TUSSEN GESKIEDENIS EN TEOLOGIE IN DIE BYBELWETENSKAPPE
}

Pieter GR de Villiers

Free State University

\section{Abstract}

\section{HISTORY, FAITH AND THE GOSPELS. PERSPECTIVES ON THE RELATIONSHIP BETWEEN HISTORY AND THEOLOGY IN BIBLICAL STUDIES}

\begin{abstract}
This article investigates the relationship between history and theology in Biblical Studies by analysing the context in which they should be understood and by referring to the research on the historical Jesus as example of this relationship. The notions of history and of faith are defined, with further discussion of the nature of the Gospels as documents that mediate the history of Jesus. It concludes with remarks on the prehistory and function of the Gospels.
\end{abstract}

\section{Inleiding}

Een van die mees tipiese kenmerke van die moderne tyd sedert die Verligting is 'n fokus op geskiedenis. In hierdie periode wat oor verskeie eeue heen veral in 'n Westerse konteks beslag vind, ontwikkel 'n historiese bewussyn wat op die gebied van godsdiens histories-kritiese metodes genereer en terselfdertyd aanleiding gee tot fundamentele navorsing oor geskiedenis. So gesofistikeerd' is die gesprek oor geskiedenis, die historiese bewussyn en historiese metodes in hierdie tydperk, dat enige verdere denke daaroor slegs in debat daarmee sou kon plaasvind selfs al beteken so 'n moontlike nuwe fase dat met die historisme gebreek sou word. Die Westerse kultuur met sy geestesprodukte is onherroeplik deur hierdie historiese bewussyn gevorm. ${ }^{2}$

Hierdie historiese bewussyn verklaar die rol van geskiedenis in die Bybelwetenskappe en die belangstelling in die historiese Jesus as 'n belangrike faset daarvan. Dit verduidelik ook waarom daar op nie-tegniese vlak in populêre kontekste soveel aandag gegee word aan publikasies oor die historiese aspekte van die Bybel (bv. die historiese Jesus, die wonders van Jesus, Jona en die vis, ens.).

Terselfdertyd daag die die fokus op die historiese die teologie nog steeds uit om helder te dink oor die verhouding van geskiedenis en teologie, of meer toegespits gesê, oor die verhouding van geloof en geskiedenis. Die antwoorde op hierdie vraag kring uit na ander motiewe, temas en probleme in die dissipline en is dus fundamenteel van aard. 'n Enkele voorbeeld of twee in sistematies teologiese kringe sal dit uitlig.

1. Vir literatuur oor die gesprek, raadpleeg die meegaande lys.

2. Sien hieroor ook die opmerkings in Ford $(1997: 5,7)$. 
Lindbeck het opgemerk kontemporêre historisisme onthul hoe deurgrondelik mense getradisioneerd is. Die menslike bestaan is georiënteer aan die tradisie, verknoop met spesifieke historiese trajekte wat die fundamentele interpretatiewe kategorieë bied waardeur menslike lewe moontlik word. Dit is sterk taal, wat 'n konstitutiewe rol toeken aan tradisie en geskiedenis in die bestaanservaring. Dit is ' $n$ behoudende standpunt as ' $n$ mens in gedagte hou hoe postmodernisme die verlede verwerp en dit vervang deur 'n eindelose en speelse skep van nuwe betekenis. Net so behoudend in vergelyking met die postmodernisme, lyk dit dan as Tracy later teologie as 'n hermeneutiese oefening beskou waarin die kontemporêre denkers in gesprek tree met die klassieke van hul tradisie vanuit hul huidige situasies met die bedoeling om insigte te kry vir die hede. Hoewel die inset van die kontemporêre denker sterker is as in die geval van Lindbeck, bly die geskiedenis vir Tracy tog direktief. Terselfdertyd toon hierdie insigte van beide Lindbeck en Tracy hoe die historiese bewussyn implikasies het vir die verstaan van die karakter van geloof, die aard van teologie as 'n dissipline en die plek van die Bybel en tradisie in teologie - om maar net enkele voorbeelde te noem. ${ }^{3}$

In die lig van hierdie agtergrond en uit hierdie voorbeelde is dit duidelik dat niemand kerklik of teologies besig kan wees sonder om met die historisme rekening te hou nie en in die proses met die kritiese denkers uit die vorige eeue in gesprek te tree nie. Dit is in hierdie konteks dat enkele opmerkings oor die verhouding geskiedenis en geloof gemaak sal word, met spesiale verwysing na die debat oor die historiese Jesus. In die proses word lyne getrek, wat nie altyd reflekteer hoe gesofistikeerd en ingewikkel die debat werklik is nie. Dit is egter belangrik om steeds te probeer vasstel waar die nodepunte is wat die tekstuur van die debat knoop en ten opsigte waarvan belangrike beslissings gemaak moet word.

\section{Die verhouding tussen geskiedenis en geloof}

Die voorafgaande inleiding loop uit op die stelling dat die verhouding tussen geskiedenis en geloof 'n sleutelkwessie is. Die historiese bewussyn het onvermydelik die teologiese verstaan van die Bybel en van die karakter van geloof beïnvloed. Enkele verdere opmerkings hieroor is nodig om te wys hoe ingrypend hierdie beïnvloeding was. Sonder om dit uit te lig, kan dit maklik gebeur dat die gesprek oor die historiese karakter van die Bybel volgens die agenda van die historisme verloop. In só 'n geval bepaal die vasgelegde spelreëls die uitkomste so onvermydelik dat die debatvoering niks anders is as om doodsbeendere van een doodskis na die ander te skuif nie.

Van binne die Bybelwetenskappe het navorsers algemeen aanvaar dat historiese ondersoek noodsaaklik is vanweë die historiese aard van Bybeltekste. Minder deursigtig is die dikwels versweë aanname wat kritiekloos saam met hierdie aanvaarding ' $n$ rol in die wetenskap begin speel het, naamlik dat die Bybel as historiese teks slegs waar is as die gebeure waarna dit verwys "werklik" plaasgevind het, dit wil sê, as hulle kritiese ondersoek oorleef deur te bewys dat hulle as gebeure korrespondeer met ekstra-tekstuele momente in die "werklike" wêreld wat objektief en empiries vasstelbaar is. Nog meer ingrypend word verder aangeneem dat geloof veral te doen het met ' $n$ historiese soektog en die vasstelling van historiese gebeure en feite, veral ten opsigte van Jesus.

Op verskillende tye is hierdie aannames deeglik bevraagteken. Een van die voorbeelde hiervan is te vind in die dun, maar deeglike werk van Boers (1979:28-29) wat nadink oor Nuwe-Testamentiese teologie vanuit ' $n$ intensiewe gesprek met die hooffigure en -strominge in die wetenskap. Hy het reeds daarop gewys hoe die geskiedenis van die vakgebied soms die imperialistiese dinamiek van die historiese benadering wil relativeer. Hierdie kritiek wil

3. Vgl. hieroor Davaney (1994:48). 
beklemtoon dat die historiese benadering net een van die wyses is waarop die Bybel gelees kan word. Selfs in 'n historiese benadering kan dit gebeur dat dit gekombineer word met vrae na die teologiese of godsdienstige fasette van die tekste wat op hul eie, naas die historiese, begryp moet word. Heeltemal verskillend van die historiese benadering is die godsdienstige benadering wat redeneer dat geloof nie afhanklik is van, of opgeskort word, deur die proses van historiese evaluering deur die historikus nie. Vanuit hierdie hoek gesien, is historiese oordele nie noodsaaklik vir geloofsvorming nie. Van belang is of die beskryfde gebeure in Bybeltekse as betekenisvol beoordeel word of nie. In die debat oor die aard van die vakgebied is hierdie posisie dikwels en met nadruk ingeneem as 'n alternatief op die konsekwenthistoriese benadering.

Boers (1979:29) skryf: "It is precisely the historical-critical investigation of Christianity which should have been able to establish that the approaches of history and of religion to these founding events were fundamentally different. It should have been able to show that in the religious approach events were tacitly assumed to be historical, which could have been wrong from a strictly historical point of view, without the religious faith being aware of its possible error in judgment. ${ }^{4}$ Historical inquiry should have accepted this as a characteristic difference in the religious approach instead of trying to impose its own approach on religion. What makes this imposition particularly intolerable is that it includes the judgment that the validity of a religion depends on the historical verification of the founding events, a judgment which is so pervasive that it is taken to be self-evident - even by believers! This is a fundamental selfmisconception of the religious approach" (my kursivering). Die ironie van die historiese ondersoek is dus dat dit op 'n wesenlike punt inkonsekwent met sy eie uitgangspunte was.

Hiermee is ' $n$ eerste tree gegee op die weg van besinning oor die historiese bewussyn van ons tyd in terme van geloof - naamlik in hoeverre die teologie sy eie aard kompromiteer deur toe te laat dat hierdie bewussyn die voorwaardes vir teologisering en teologiese inhoude bepaal en stuur. Dit vereis nadere ondersoek deur dieper in te gaan op die vraag wat geloof is.

\section{Die aard van geloof}

Twee voorbeelde van die wyse waarop geloof verstaan word, sal die probleem onder bespreking illustreer.

Crossan wil as jarelange navorser oor die historiese Jesus uitvoering gee aan sy verstaan dat geloof ' $n$ handeling van vertroue in die historiese Jesus as manifestasie van God is..$^{5}$ In hierdie geval is historiese inligting oor wie Jesus is, fundamenteel vir geloof (1994:20).

Aan die ander kant sien Johnson (1996:133) geloof in die hede en in Bybelse tye as die ervaring van die teenwoordige krag van Jesus. Die Christendom handel oor 'n ervaring van 'n nuwe teenwoordigheid van Jesus wat transformatiewe, transendente en persoonlike kragte in

4. Cf. Johnson (1996:146) om iets van die implikasie van só 'n standpunt te begryp: "When we read of the return of the Son of man placed in the mouth of Jesus in the Gospels, therefore, we are not in the least worried about the 'historical' basis for that statement. What is significant (for us now!) is the existential import of the statement: our life is lived under a certain judgment."

5. Hy skryf: "it is certainly possible to have Christian faith without any constitutive reference to the historical Jesus. It is called Gnostic Christianity and its possible trajectory is already latent, at least with hindsight, in the Gospel of Thomas and those Thomas-style Christians Paul knew at Corinth in the early fifties. And I presume it is still with us today. Apart from that, however, Christian faith, at least in Catholic Christianity, is belief in the historical Jesus as the manifestation of God. I think, in other words, that at the heart of any form of Catholic Christianity there is always a dialectic between an historically-read Jesus and a theologically-read Christ. But any analysis of an historical Jesus must be open to the disciplined historical methods of its contemporary world and must be able to stand up to its judgments without special pleading." Dit is belangrik hoe Davaney (1994:49-51) die belangrike onderskeid tussen Crossan en die konsekwente postmodernisme uitwys. 
die gemeenskap ontketen. Geloof was nog nooit gebou op 'n historiese rekonstruksie van Jesus nie, al het geloof altyd sekere aansprake oor die historiese Jesus ingehou. Geloof word dus deur geskiedenis geprofileer of verduidelik, maar dit word in die eerste instansie gegenereer deur die opstanding as die eerste en voldoende oorsaak. Die opstanding self kan nie as 'n historiese vertelling gelees word nie, want dit transendeer tyd en ruimte. Historiese kennis is te beperk om die opstanding te begryp. Tog is opstanding deel van die geskiedenis omdat dit die lewens en optrede van gelowiges van die begin af stuur.

Hierdie twee uiteenlopende verklarings van geloof vind hul wortels in die wyse waarop oor geskiedenis en teologie nagedink word. Terwyl Crossan dialekties met geloof en geskiedenis wil werk en sy primêre uitgangspunt vanuit die geskiedenis na die teologie ${ }^{6}$ is, is Johnson se vertrekpunt die teenoorgestelde. $\mathrm{Hy}^{7}$ wil vanuit 'n teologiese konteks ook nadink oor die geskiedenis. Dit sal verder hieronder bespreek word, omdat dit meer kompleks as net 'n kwessie van uitgangspunte is. Eers moet egter 'n meer fundamentele saak ondersoek word, want navorsers wat 'n historiese benadering tot geloof het, opereer met 'n verstaan van geskiedenis wat nie altyd duidelik genoeg uitgewerk word nie.

\section{Die aard van geskiedenis}

Dit is tog opvallend dat navorsers wat oor die historiese Jesus en oor historiese aspekte van die Nuwe Testament werk min oor geskiedenis as doenigheid reflekteer. Terwyl almal toegee dat geskiedenis ' $n$ rekonstruksie is en dus subjektief van aard is, word die ingrypende aard van hierdie rekonstruktiewe werk eintlik eers werklik duidelik wanneer die volgende onder loep kom:

3.1 Reeds met die eerste oogopslag sal die gedagte van rekonstruksie die subjektiewe moment na vore bring. Geskiedenis is in die eerste plek 'n menslike aktiwiteit waardeur interpretasie plaasvind. Daar is nie so iets soos "geskiedenis" wat wag om onthul en beskryf te word nie. In die interpreterende doenigheid word sekere gebeure deur die historiograaf herken en benoem as betekenisvol genoeg en dan uitgelig om deel te word van wat as geskiedenis beskou word. Deur hierdie gebeure uit te lig, word ander uitgeskakel, verswyg of tot die periferie verplaas. Terselfdertyd werk geskiedenis net met verskynsels wat onder woorde gebring kan word en wat 'n drie-dimensionele karakter het. Belangrike nie-verbale momente soos ligaamstaal, emosies, vooroordele en fisieke handelinge kan per definisie moeilik enige plek in die historiese beskrywing kry, hoewel hulle soms 'n deurslaggewende rol daarin kan speel. ${ }^{8}$ Ewe ingrypend is die ordening wat hierna plaasvind. Die geselekteerde momente word sistematies in verband met mekaar gebring, meestal in die vorm van oorsaak en gevolg. Dit alles het 'n retoriese karakter, bedoel om 'n bepaalde effek

6. Hy weier self om geskiedenis en teologie te skei en dring daarop aan dat hy teologies werk. Sien Van Beeck (1994:83-86).

7. Dit is insiggewend hoe hierdie siening oorvleuel met ander kontemporêre posisies. Rahner, in reaksie teen 'n dosetiese verstaan van Jesus in populêre Katolieke denke, beklemtoon dat getuienis oor gebeure in Jesus se lewe noodsaaklik is om oor soteriologie te kan skryf. Dit gaan egter om 'n fokus op die humaniteit van Jesus wat heilsimpliksies het. Sien hieroor en oor ander sistematiese bydraes (Küng, Schillebeeckx), Ludwig (1994:62-64). Crossan (1994:153), in sy reaksie op Ludwig, vertel dat hy nooit hierdie teoloë of van die Suid-Amerikaanse bevrydingteoloë gelees het nie.

8. Die Nuwe Historisme speel tot 'n sekere mate hierop in deur sy anekdotiese benadering tot geskiedskrywing. Die mikroverhaal wat normaalweg in die tradisionele historiografie deur die romantiese, heroïese benadering uitgeluit is, word sleutels vir 'n revisionistiese geskiedskrywing. Hierdie anekdotiese vertellings funksioneer dikwels om dit wat as histories onvertelbaar beskou is as histories deurslaggewend te rekonstrueer. Dit is egter 'n onderwerp wat in 'n ander konteks ontwikkel sal word. 
te bereik deur ander te beïnvloed en te stuur. ${ }^{9}$ Die soektog na die verlede word onderneem om die hede te verstaan. ${ }^{10}$

Vanuit hierdie lig gesien, is die beperktheid van geskiedenis as modus van kennis duidelik. Hierdie beperktheid is al duidelik genoeg in geskiedskrywing oor kontemporêre sake. Wanneer die antieke historiese beskryf word, is die beperktheid soveel meer akuut.

Terselfdertyd word dit duidelik hoe hierdie interpretatiewe beeld van geskiedenis dit in 'n sekere sin baie na aan teologie as beskrywende en hermeneutiese doenigheid laat beweeg. Dit is daarom van buitengewone belang om die onverbiddelike logiese uiteinde hiervan raak te sien in 'n onlangse opmerking van Lüdemann, soos nou van nader bekyk moet word.

3.2 Die subjektiewe rol van die interpreteerder van 'n teks word so wyd aanvaar en geleer dat 'n mens dit maar as 'n aksioom in die wetenskap kan beskou. Die rol van die interpreteerder is byvoorbeeld deurslaggewend in die keuse van wat as geskiedenis kwalifiseer, hoe bronne gehanteer word en hoe 'n sintese uit hierdie bronne opgebou word. Ewe opvallend is die subjektiewe aard van die retoriese karakter van historiografie. Dit blyk uit 'n analise van die werk van die historici in die konteks van die Jesus Seminaar dat hulle met hulle historiese rekonstruksies wil wegbeweeg van voorstellings wat volgens hulle gevestigde bolwerke in die tradisionele teologie is. Hieronder val byvoorbeeld ' $n$ tradisionele patriargale Godsbeeld wat 'n straffende soteriologie van verdoemenis en vergelding in die hand werk of ' $n$ bepaalde kerkbeeld wat ' $n$ bemiddelende heilsinstansie tussen God en mens inskuif. Geskiedenis word op die manier ' $n$ wapen in die stryd van die individuele navorser teen gewaande teologiese drogbeelde. Dit word hieruit duidelik hoe ingrypend die interpreteerder se sosiale situering en die psigologiese persepsies wat daarbinne funksioneer historiografie - en dus wetenskapsbeoefening - bepaal, terwyl dit ook verstaanbaar word waarom die geskiedenis op 'n bepaalde wyse gerekonstrueer word.

Hierdie opmerkings word verhelder deur 'n onlangse publikasie van die Duitse NuweTestamentikus, Lüdemann. As inleiding tot die boek skryf hy 'n brief aan Jesus waarin hy die blote menslikheid van Jesus teenoor die vergoddelikte Christusbeeld van die evangelies en die kerk benadruk. Hy vertel van 'n droom waarin hy hom uiteindelik self bevry van sy vrees, skuld en verlamming wat sy godsdienstige ervarings by hom opgewek het. Die retoriek is duidelik: tradisionele godsdiens dra swaar aan die las van die negatiewe, sodat dit verdien om tot 'n einde gebring te word. Opvallend egter is die motivering vir sy afskeid aan Jesus wat hierop volg; "überhaupt bezweifelte ich, dass Erforschung von Geschichte einschliesslich deiner Verkündigung zur Ausbildung eines Moralkodex in der heutigen Zeit führt, der verbindlich sein kann" (Lüdemann 1998:16). Sy historiese werk, vervolg hy, lewer nouliks iets op in 'n algemene etiese sin of as oriëntering vir die praktiese lewe. Sy geloof tot in daardie stadium het duidelik op projeksies of op ontoetsbare veronderstellinge berus. Hy kan nie verder aan die normatiewe krag van geskiedenis of historiese feite glo sonder om sy eie subjektiewe voorstellinge in wetenskaplike gewaad ter sprake te bring nie $^{11}$ Jesus se lewe is uiteindelik vir hom té tydsgebonde om op enige manier in 'n moderne situasie oorgedra te word. Dit beteken dat ons vandag rasionele optrede moet kan uitwerk wat onafhanklik is van Jesus, sy hemelse Vader of enige ander Godheid. Seminale motiewe

9. In die geval van die Jesus Seminaar is hierdie retoriese funksie van geskiedskrywing opvallend, soos blyk uit die laaste hoofstuk van Funk (1996). Sien egter ook verder hier onder.

10. Sien hieroor verder Johnson (1996:81-104).

11. "Ich kann nicht weiterhin an die normative Kraft der Geschichte oder historischer Fakten glauben, ohne meine eigenen subjektiven Vorstellungen in wissenschaftlicher Verkleidung mit ins Spiel zu bringen” (ibid.). 
van en probleme in die Verligting, naamlik tydgebondenheid, historiese partikulariteit, subjektiwiteit en rasionaliteit kom hier tot wasdom. ${ }^{12}$

3.3 Geskiedenis word, in die lig van die vorige paragraaf, 'n glibberige beginpunt vir geloof, veral as die sogenaamde "werklike" en objektiewe karakter daarvan so duidelik en konsekwent gedekonstrueer kan word. 'n Geloofsbeeld wat voorgee om aan geskiedenis geörienteer te wees, kan nie aanspraak maak dat dit op die spreekwoordelike rots gebou is nie. Die aard van geskiedenis skep duidelike probleme vir die verstaan van geloof. Dit is reeds in 'n vroeë stadium só ervaar. Die opmerkings van Boer wat hierbo aangehaal is, is byvoorbeeld reeds aan die begin van die negentiende eeu deur Stäudlin voorafgeskadu. Hy wou ook histories met die Nuwe Testament werk, ${ }^{13}$ maar wou, tipies van sy tyd, normatiewe en ewige waarhede nie tot 'n sekondêre area van ondersoek naas die historiese uitskuif nie (teenoor Gabler). Reeds in die histories deskriptiewe fase is hierdie teologiese momente aanwesig. ${ }^{14}$ Daarom moet die Bybel van begin tot einde vanuit ' $n$ teologiese hoek gelees word met die bewussyn van hul besondere karakter en van die interpreteerder se eie insette. Sekere dimensies van Bybelse tekste bly te verborge vir 'n historiese benadering (Kümmel 1973:114; Frei 1974:167). "Furthermore, the merely historical interpreter cannot adequately appreciate and clarify the weight and nature of Jesus' teachings. He sees everywhere only history and historical relationships. But Jesus' teaching is not merely something historical, not merely a part of history, not simply of a historical nature; it also contains eternal, unchangeable, divine truths which one can fully explain to himself and make comprehensible to others, never on the ground of history and grammar alone, but rather by one's own spirit, by meditation, by elevation to ideas of the reason, and from [the truths] themselves" (Stäudlin, aangehaal in Kümmel 1973:114).

Die verouderde terminologie en idealistiese reduksie ${ }^{15}$ van teologiese momente tot "ewige" waarhede in hierdie aanhaling ten spyt, illustreer dit voldoende hoe vroeg en sterk die beperkte rol en waarde van geskiedenis in die interpretasie van die Bybel ervaar is.

\section{Die Evangelies as geloofs- en historiese dokumente}

Navorsers wat deelneem aan die Jesus Seminaar deel sekere fundamentele uitgangspunte. ${ }^{16}$ Tot dusver rekonstrueer hulle aan die hand van geselekteerde en gerekonstrueerde bronne soos die Evangelie van Tomas en Q sekere woorde van Jesus as histories (en dus seker en waar). Hierdie woord kwalifiseer Jesus as 'n wyse persoon wat 'n onbemiddelde, revolusionêre godsdiens verkondig wat onafhanklik van instellinge soos die kerk funksioneer. ${ }^{17}$ Fundamenteel

12. Van Beeck (1994:87-89) se beskrywing hoe Lessing die teologiese benadering tot die Christendom in terme van die belydenis van die kerk beskou as gedoem tot mislukking in agtiende-eeuse Europa (!) met sy rasionele inslag beskou, is hier insiggewend.

13. "Although we have never doubted the need and usefulness of the historical interpretation, we have been of the opinion, nevertheless, that this is not the only true and sufficient one, that it has been misused by most, and that Christianity and theology have suffered seriously from its being extended beyond its limits and unjustly used by those with false principles or none at all" (ibid.).

14. Dit is soms kenmerkend van die historiese benadering dat dit die rol van subjektiewe momente in historiese konstruksie onderskat, hoewel die teenwoordigheid daarvan erken word. Crossan (1994:153) weier byvoorbeeld om te aanvaar dat teologiese kwessies wat hy opper van die begin van sy ondersoek as ' $n$ motiverende faktor teenwoordig was.

15. Sien verder hieronder oor die bemiddelende funksie van tekste waar die afwatering van tekste tot "waarhede" of "gebeure" agter hulle, bespreek word.

16. Sien bv. Funk (1997:7-8).

17. Funk (1996:302) skryf byvoorbeeld: "When the name Jesus is mentioned, 'religion' is assumed to be the subject. But, in fact, the Jesus of whom we catch a glimpse in the gospels may be said to have been irreligious, irreverent, and impious. The first word he said, as Paul Tillich once remarked, was a word against religion in its habituated form; because he was indifferent to the formal practice of religion, he is said to have profaned the temple, the 
aan hierdie analise is dat die gordyn van die opstanding oor die Jesusverhaal afgeruk moet word (Funk 1996:303-304) sodat ons agter hierdie produk van kerklike vervalsing tot die egte historiese Jesus kan deurdring.

Twee vrae is hier van belang: eerstens, laat die aard van die bronne hierdie konklusies toe en tweedens, hoe word toegang tot die geskiedenis van Jesus gebied?

\subsection{Die bewyskrag van die bronne}

Belangrike vrae is oor die bewyskrag van die bronne in die historiese Jesus ondersoek gevra. Die hipotetiese aard van die bronne is sonder meer bekend. Die probleem is nie soseer dat Q as bron uitgewys word nie, maar dat die omvang en tradisiegeskeidenis daarvan so probleemloos gerekonstrueer word. Die Evangelie van Tomas is nie minder glibberig nie, veral nie as in gedagte gehou word dat slegs 'n klein deel daarvan as eg aanvaar word nie. ${ }^{18}$ Die grotere probleem is egter te vinde in die manier waarop die evangelies self die geskiedenis van Jesus aanbied - 'n punt wat meer aandag verdien.

\subsection{Die geskiedenis van Jesus in die evangelies}

Een van die belangrikse faktore in die nadenke oor die historiese inhoud en karakter van die Bybel wat in uitleg daarvan verreken moet word, is dat die toegang daartoe slegs tekstueel verleen kan word. Hierdie toegang tot historiese ondersoek verdien meer aandag, nie net omdat dit iets moet sê oor die metode van historiese ondersoek nie, maar ook oor die vorm waarin die toegangsdokumente gegiet is.

Die tekstualteit van die geloofsdokumente is veral in resente tye sterk in fokus gebring. Die evangelies word nou al 'n geruime tyd in die Nuwe-Testamentiese wetenskap met literêre modelle gelees. Hierdie benaderings beklemtoon dat die boeke ' $n$ geslote narratiewe wêreld aanbied wat nie sonder skade uitmekaar gehaal of in 'n een tot een verhouding met hul ontstaanswêreld geplaas kan word nie. Hierdie geslote wêreld reflekteer 'n basiese historiese patroon. ${ }^{19}$ 'n Teksdeel ontvang sy betekenis in terme van ander teksdele en die geheel. Om dus 'n gedeelte van 'n teks uit te lig en op sy eie te interpreteer, is 'n waagstuk. Die Bybelse tekste reflekteer reeds seleksie en sistematisering, wat die funksie van sulke teksdele tegelykertyd beperk en afsluit. ${ }^{20}$

Dit is des te meer die geval wanneer ' $n$ mens dieselfde historiese patroon in al die evangelies opmerk asof daar 'n noue verband is tussen die genre van Evangelie en historiese inhoude. Dit beteken dat die integriteit van die teks eerbiedig moet word. Die finale vorm speel 'n fundamentele rol ten opsigte van die inhoud. Wanneer 'n historiese Jesus agter die vorm uitgelig word, word wat reeds voorheen geselekteer is om in hierdie historiese patroon te pas, daaruit weggeneem en in ' $n$ nuwe samehang ingeskuif. Dit is nie net problematies omdat die bronne wat daarvoor gebruik word hipoteties en fragiel is nie, maar laat ook 'n belangrike perspektief op die inhoude weg, want die opstanding definieer en bepaal die historiese patroon wat in die vier Evangelies aangebied word. Terwyl die opstanding aan die teksdele in die

sabbath, and breached the purity regulations of his own legacy; most important of all, he spoke of the kingdom of God in profane terms - that is, nonreligiously." Afgesien van die feit dat hier 'n idiosinkratiese verstaan van godsdiens aangebied word, toon hierdie en ander verreikende opmerkings in die epiloog tot sy boek hoeveel ingrypende afleidings uit hul gerekonstrueerde bronne gemaak word.

18. Sommige van die probleme in die verband word deur Van Beeck (1994:89-93) uitgewerk.

19. Johnson het hierdie patroon nader uitgewerk en dit saamgevat in die opmerkings dat die evangelies konsekwent vir Jesus aanbied as die een wat in radikale gehoorsaamheid aan God en in selfopofferende liefde teenoor ander sekere dade verrig en woorde uiter (Johnson 1996:122-140).

20. Watson (1994:226-227) noem verskeie voorbeelde. 
evangelies betekenis toeken, word hierdie teksdele in 'n historiese benadering losgemaak van hierdie bepalende perspektief en word aan hulle betekenis toegeken in 'n nuwe perspektiwiese vertelling wat nie gekontroleer kan word nie of wat deur 'n moderne leser verskaf word.

Beteken dit dat toegang tot die historiese Jesus feitlik onmoontlik word? Hieraan moet nou aandag gegee word.

\section{Die Evangelies en hul voorgeskiedenis}

Uit die vorige afdeling het dit geblyk hoe belangrik die vorm en dus die finale teks van die Evangelies is. Verskeie navorsers het die afgelope paar jaar vanuit 'n teologiese perspektief hieraan aandag gegee, onder meer in die dikwels omstrede kanonieke lees van Bybelse tektse soos onder andere deur Childs. Op minder metodologiese vlak en meer vanuit sistematiese hoek het Frei (1974) hieroor nagedink in sy baanbrekende The Eclipse of Biblical Narrative. Onlangs het die integriteit van die Bybeltekste ook onder loep gekom in die werk van Watson (1994), onder meer in dialoog met Childs en Frei. Watson merk tereg op dat die eerbied vir die integriteit van die teks té maklik tot 'n dosetisme kan aanleiding gee waar die historiese Jesus 'n gevangene van die teks word en niks meer is as 'n linguïstiese realiteit nie (1994:225).

In teenstelling hiermee moet onthou word dat tekste verwys na ekstra-tekstuele gegewens, sodat die moontlikheid om oor die situasie rondom en voor die teks te praat, nie opgehef kan word nie. Die teks bied dus toegang tot die historiese Jesus. ${ }^{21}$ Hier is dit belangrik om te onthou dat net soos wat die teks nie sommer net opgebreek kan word en historiese rekonstruksies as probleemloos en seker aangebied kan word nie, net so kan die finale teks nie gesien word as in 'n een-tot-een verhouding tot die werklikheid wat daarin ter sprake kom nie. Die vertelde wêreld in die teks is nie gelyk te stel aan die vertellerswêreld of die wêreld waarna die teks verwys nie. ${ }^{22}$

\section{Funksie}

Uiteindelik moet steeds onthou word hoe deurslaggewend die funksie van 'n teks is. Die moderne literatuurwetenskap het ons geleer dat vorm, inhoud en funksie 'n triade vorm wat so geïntegreerd is dat enige uitleg wat een hiervan ontbeer, gedoem is tot eensydigheid of mislukking. Hierbo is 'n paar punte uitgewys oor die rol van funksie in die kontemporêre interpretasies van die historiese Jesus. Hier moet net kortliks daarop gewys word dat die funksie van die evangelietekste self in spel gebring moet word by die uitleg daarvan. Hoewel funksie berug moeilik is om vas te stel, is dit in die geval van Bybelse tekste nogal interessant hoe helder dit soms na vore kom in sulke tekste soos Johannes 20:31. As ons al hoe meer sensitief raak vir die vorm van die toegangsdokumente, moet ons terselfdertyd meer gevoelig wees vir hul ontstaansfunksie. Iets hiervan kom na vore wanneer Johnson skryf: "The situation with the Christian's memory of Jesus is not like that of a long-ago lover who died and whose short time with us is treasured. The situation, rather, is like that of a lover who continues to live with the beloved in a growing and maturing relationship. In such a situation, the memory of the past is constantly affected by the continuing experience of the other in the present... The issue of where my wife and I had our first date, or realized we were in love, or even made our vows, is of much less significance to each of us than the issue of whether our love is alive and powerfully real now" (Johnson 1996:143). Die evangelies is nie net dokumente wat toegang

21. Voorbeelde van rekonstruksies van historiese Jesus gebou op die beginsel van die integriteit van die teks word dikwels in Watson (1994) gegee. Saam met Johnson (1996) bied dit 'n goeie voorbeeld vir verdere werk in dié verband.

22. Lees Watson (1994:230) se interessante bespreking van Origines se kritiek op Celsus in 'n pre-moderne konteks hieroor. 
wil bied tot die verlede nie - hulle is ook en veral tekste wat die hede en die toekoms wil ontsluit.

\section{Gevolgtrekking}

Dit is uiteraard ' $n$ vraag of ons samelewing dieselfde historiese bewussyn sal bly deel as wat tans in die teologie aanvaar word en wat so sterk inwerk op teologie en die Bybelwetenskappe. Sekere krake is merkbaar deur die werk van die postmodernisme wat historiografie bevraagteken en soms selfs verwerp. Tog lyk dit of daar ook binne 'n postmodernistiese konteks ' $n$ oortuiging posvat dat daar ruimte is vir historiografie..$^{23}$ Indien dit in die historiese bewussyn van ons tyd kontinueer, sal die teologie meer as ooit aandag moet skenk aan Boers se opmerking dat té maklik en té eenvoudig toegelaat word dat die historiese benadering teologiese doenigheid stuur en die teologiese agenda bepaal.

23. Hierdie artikel is een in 'n reeks oor die verhouding tussen geloof en geskiedenis, wat afgesluit sal word met 'n bespreking van die Nuwe Historisme. 


\section{BIBLIOGRAFIE}

Balla, P 1997. Challenges to New Testament Theology. Tübingen: Mohr Siebeck.

Barton, SC 1999. New Testament Interpretation as Performance. SJT 52, 179-208.

Boer, R 1998. Deutero-Isaiah: Historical Materialism and Biblical theology, Biblical Interpretation 6 (1998), 180-204.

Boers, H 1979. What is New Testament Theology? The Rise of Criticism and the Problem of a Theology of the New Testament. Philadelphia: Fortress.

Brett, MG 1991. Biblical Criticism in Crisis? The impact of the Canonical Approach on Old Testament Studies. Cambridge: Cambridge University Press.

Büchsel, F 1935. Theologie des Neuen Testaments. Geschichte des Wortes Gottes im Neuen Testaments. Gütersloh: Bertelsman.

Bultmann, R 1952. Theology of the New Testament 1. The Message of Jesus. The Kerygma of the Earliest Church. The Theology of Paul. London: SCM.

Conzelmann, H 1969. Grundriss der Theologie des Neuen Testaments. Tübingen: Mohr.

Crossan, JD 1994. The Historical Jesus in Earliest Christianity, in J Carlson and RA Ludwig (eds.), Jesus and Faith. A Conversation on the work of John Dominic Crossan. Maryknoll, N.Y.: Orbis.

Crossan, JD 1994. Responses and Reflections, in J Carlson and RA Ludwig (eds.), Jesus and Faith. A Conversation on the work of John Dominic Crossan. Maryknoll, N.Y.: Orbis.

Cullmann, O 1965. Heil als Geschichte. Tübingen: Mohr.

Davaney, SG 1994. A Historicist Model for Theology, in Carlson, J and Ludwig, RA (eds.), Jesus and Faith. A Conversation on the work of John Dominic Crossan. Maryknoll, N.Y.: Orbis.

De Villiers, PGR 1999. The polemical task of feminist spiritualities. Scriptura Vol 70, 195209.

Donahue, JR 1996. The Literary Turn and New Testament Theology. JSOT 76, 250-275.

Ford, DF (ed.) 1997. The Modern Theologians. An Introduction to Christian Theology in the Twentieth Century. $2^{\text {nd }}$ ed. Cambridge, Ma.: Blackwell.

Frei, HW 1974. The Eclipse of Biblical Narrative. A Study in Eighteenth and Nineteenth Century Hermeneutics. New Haven \& London: Yale University Press.

Funk, RW 1996. Honest to Jesus. Jesus for a New Millennium. San Francisco: HarperSanFrancisco.

Gadamer, H-G 1975. Truth and Method. New York: Continuum.

Gnilka, J 1994. Theologie des Neuen Testaments. Freiburg: Herder.

Goppelt, L 1981. Theology of the New Testament. 1. The Ministry of Jesus in its Theological Significance. Grand Rapids: Eerdmans.

Graham, SL and Moore, SD 1997. The Quest of the New Historicist Jesus. Biblical Interpretation 4, 438-463.

Hamilton, P 1996. Historicism. The New Critical Idiom. London and New York: Routledge.

Hemer, CJ 1986. The Letters to the Seven Churches of Asia in their Local Setting. (JSNTSS 11). Sheffield: University of Sheffield.

Hübner, H 1990. Biblische Theologie des Neuen Testaments. 1. Göttingen: Vandenhoeck.

Hurtado, L 1999. New Testament Studies at the Turn of the Millennium: Questions for the Discipline? SJT 52, 158-178. 
Jeanrond, WG 1998. The Significance of Revelation for Biblical theology. Biblical Interpretation 6, 243-258.

Johnson, LT 1996. The Real Jesus. The Misguided Quest for the Historical Jesus and the Truth of the Traditional Gospels. San Francisco: HarperSanFrancisco.

Kümmel, WG 1972. The Theology of the New Testament. London: SCM.

Kümmel, WG 1973. The New Testament. The History of the Investigation of Its Problems. London: SCM.

Kwok, P 1998. On Color-coding Jesus: an Interview with Kwok Pui-Lan, in Sugirtharajah, RS 1998. The Postcolonial Bible. Sheffield: Sheffield Academic Press. (The Bible and Postcolonialism 1), 176-188.

Lentricchia, F 1989. Foucault's Legacy: A New Historicism?, in Veeser 1989.

Lüdemann, G 1998. Der Grosse Betrug und was Jesus wirklich sagte und tat. Lüneberg: $\mathrm{Zu}$ Klampe.

Ludwig, RA 1994. Reconstructing Jesus for a Dysfunctional Church, in J Carlson and RA Ludwig (eds.), Jesus and Faith. A Conversation on the work of John Dominic Crossan. Maryknoll, N.Y.: Orbis.

Lund, N 1992. Chiasmus in the New Testament. A Study in the Form and Function of Chiastic Structures. Peabody: Hendrickson.

Merk, O 1980. Biblische Theologien. TRE, band 6, 455-477.

Moore, SD 1997. History after theory? Biblical Studies and the New Historicism. Biblical Interpretation 4, 289-299.

Ogden, SM 1996. Theology and Biblical Interpretation. History of Religions.

Ollenburger, BC, Martens, EA and Hasel GF (eds.) 1992. The Flowering of Old Testament Theology. A Reader in Twentieth Century Old Testament Theology, 1930-1990. Winona Lake, Ind.: Eisenbrauns. (Sources for Biblical and Theological Study).

Perdue, LG 1994. The Collapse of History. Reconstructing Old Testament Theology. (Overtures to Biblical Theology). Minneapolis: Fortress.

Räisänen, H 1990. Beyond New Testament Theology. A Story and a Programme. London: SCM.

Räisänen, H 2000. Neutestamentliche Theologie? Eine religionswissenschaftliche Alternative. SB 186. Stuttgart: Verlag Katholische Bibelwerk.

Riches, J 1998. Text, Church and World: In Search of a Theological hermeneuetic. Biblical Interpretation 6, 205-234.

Ringe, S 1998. Places at the Table: Feminist and Postcolonial Biblical Interpretation, in Sugirtharajah, RS 1998. The Postcolonial Bible. Sheffield: Sheffield Academic Press. (The Bible and Postcolonialism 1), 136-151.

Rowlett, L 1992. Inclusion, Exclusion and Marginality in the Book of Joshua. JSOT 55, 15-23.

Sanders, EP 1977. Paul and Palestinian Judaism. London: SCM.

Sandys-Wunsch, J \& Eldredge, L 1980. JP Gabler and the Distinction between Biblical and Dogmatic Theology: Translation, Commentary, and Discussion of his Originality. SJT 33, 133-158.

Schwarz, RM 1990. Introduction: On Biblical Criticism, in RM Scwarz (ed.) The Book and the Text. The Bible and Literary Theory, Cambridge Ma.: Blackwell, 1-15.

Schwarz, RM (ed.) 1990. The Book and the Text. The Bible and Literary Theory. Cambridge Ma. and Oxford: Blackwell. 
Segovia, FF 1998. Biblical Criticism and Postcolonial studies: Toward a Postcolonial Optic, in Sugirtharajah, RS 1998. The Postcolonial Bible. Sheffield: Sheffield Academic Press. (The Bible and Postcolonialism 1), 48-65.

Sheppard, GT 1998, in McKim, D. Historical Handbook of Major Biblical Interpreters. Downers Grove, Ill.: InterVarsity, 257-280.

Sherwood, Y 1997. Rocking the Boat: Jonah and the New Historicism. Biblical Interpretation 5, 364-402.

Stauffer, E 1948. Die Theologie des Neuen Testaments. Gütersloh: Bertelsmann.

Stendahl, K 1962. Biblical theology, Contemporary, IDB 418-432.

Stuhlmacher, P 1997. Biblische Theologie des Neuen Testaments. 1. Grundlegung von Jesus zu Paulus. Göttingen: Vandenhoeck.

Sweeney, MA 1998. Reconceiving the Paradigms of Old Testament Theology in the PostShoah Period, Biblical Interpretation 6, 142-161.

Sugirtharajah, RS 1998. The Postcolonial Bible. Sheffield: Sheffield Academic Press. (The Bible and Postcolonialism 1).

Van Beeck, J 1994. The Quest of the Historical Jesus. Origins, Achievements and the Specter of Diminishing Returns, in Carlson, J and Ludwig, RA (eds.), Jesus and Faith. A Conversation on the work of John Dominic Crossan. Maryknoll, N.Y.: Orbis.

Veeser, HA (ed.) 1989. The New Historicism. New York \& London: Routledge.

Watson, F 1994. Text, Church and World. Biblical Interpretation in Theological Perspective. Grand Rapids: Eerdmans.

Watson, F 1998. A Response to John Riches. Biblical Interpretation, 6, 235-242. 